\title{
ДОСВІД ЗАПРОВАДЖЕННЯ МОДЕЛІ ПРОБЛЕМНО-ОРІЄНТОВАНОГО НАВЧАННЯ У ЗАПОРІЗЬКОМУ ДЕРЖАВНОМУ МЕДИЧНОМУ УНІВЕРСИТЕТІ
}

\author{
Ю. М. Колесник, М. О. Авраменко, С. А. Моргунцова, І. О. Юрченко \\ Запорізький державний медичний університет
}

\section{EXPERIENCE IN IMPLEMENTATION OF PROBLEM-BASED LEARNING IN ZAPOROZHYE STATE MEDICAL UNIVERSITY}

\author{
Yu. M. Kolesnyk, M. O. Avramenko, S. A. Morhuntsova, I. O. Iurchenko \\ Zaporozhye State Medical University
}

\begin{abstract}
Проблемно-орієнтоване навчання в українській вищій медичній освіті з’явилося відносно недавно. Зважаючи на передовий світовий досвід, можна впевнено говорити про його актуальність та інноваційність. У даній роботі висвітлено досвід Запорізького державного медичного університету щодо впровадження проблемно-орієнтованого навчання у студентів молодших курсів медичного факультету у рамках проекту 530519-Tempus-1-2012-1-UK-TEMPUS-JPCR “Створення Міжрегіональної мережі національних центрів медичної освіти, головним напрямом яких $є$ впровадження проблемно-орієнтованого навчання з використанням віртуальних пацієнтів” (“еPBLnet”). Описано особливості адаптації навчального плану, використання платформи OpenLabyrinth для створення кейсів на базі віртуальних пацієнтів, показано роль створеного Медичного освітнього центру при ЗДМУ.
\end{abstract}

Problem-based learning appeared in the Ukrainian higher education fairly recently. Taking into account world's best practices we can speak with certainty about its relevance and innovation. This work describes the experience of Zaporozhye State Medical University in PBL implementation into the junior medical students' education in frames of Tempus project 530519-Tempus1-2012-1-UK-TEMPUS-JPCR "Establishment of the Supra-Regional Network of the National Centers in Medical Education, focused on PBL and Virtual Patients” (“ePBLnet”). It also depicts some peculiarities in curriculum adaptation, OpenLabirynth platform use for case development based on virtual patients and role of Medical Education Centre of ZSMU.

Вступ. Методика проблемно-орієнтованого навчання у педагогіці розробляється з середини 50-х років XX століття. 3 часом вона не тільки не втрачає актуальності, а навпаки, широко використовується і запроваджується у нові галузі освіти. Більш ніж у 80 \% медичних шкіл США, Канади, Австралії прийнята проблемно-орієнтована методологія викладання, яка використовується для введення студентів у світ реальних або гіпотетичних клінічних ситуацій. Структура викладання, розроблена в Західному університеті Каліфорнії, служить основою багатьох навчальних посібників і викладацьких планів у таких університетах, як Гарвард і університет Мак-Мастера. У медичній освіті проблемно-орієнтоване навчання почало впроваджуватися в університеті Мак-Мастера в Канаді в середині 1960-х років. Незабаром після цього три інших медичних школи - університет Лімбурга в Маастрихті (Нідерланди), університет Ньюкасла
(Австралія) і університет в Нью-Мексико (США) - адаптували розроблену модель і впровадили їі у своїй педагогічній практиці. В подальшому це відіграло важливу роль у своєрідному розділі сфер академічного впливу [1-3].

Основна частина. Проблемно-орієнтоване навчання у Запорізькому державному медичному університеті (ЗДМУ) бере свій початок з жовтня 2012 р., коли було започатковано грантовий проект 530519-Tempus-1-2012-1-UK-TEMPUS-JPCR “Створення Міжрегіональної мережі національних центрів медичної освіти, головним напрямом яких $є$ впровадження проблемно-орієнтованого навчання з використанням віртуальних пацієнтів” (“ePBLnet”).

Освітній проект “еPBLnet” завершено у січні 2016 р. Учасниками проекту були університетипартнери з країн Європейського Союзу (Великобританія, Греція та Кіпр), а також країни постра- 
дянського простору (Україна, Грузія та Казахстан). Загальна кількість партнерів становила 9.

У рамках проекту “еPBLnet”, з метою ефективної реалізації цілей і завдань, а також концепцією розвитку університету на 2013-2020 рр. при ЗДМУ було створено Медичний освітній центр.

Організація освітнього процесу за методикою проблемно-орієнтованого навчання в рамках виконання Tempus-проекту еPBLnet базується на вивченні протягом тижня одного конкретного клінічного випадку, який носить робочу назву “кейс”. Структура кейсу побудована таким чином, що студенти поступово отримують від тьютора інформацію щодо скарг, анамнезу, супутньої інформації про стан хворого, даних фізикального, інструментального та лабораторного обстеження хворого. Після отримання кожного блоку інформації студенти розпочинають дискусію між собою (це важливий момент - дискусія проводиться всередині групи студентів, тоді як викладач-тьютор виконує роль спостерігача, який мотивує студентів та направляє дискусію у випадку, коли вона непродуктивна). Основними завданнями дискусії є: виділити в отриманому блоці інформації вказівки, які дозволяють запідозрити ураження тієї чи іншої системи, а також містять важливу інформацію про пацієнта; скласти список питань для самостійного вивчення на підставі тих понять, термінів, даних, які студентам невідомі; скласти список робочих гіпотез. При цьому необхідно зауважити, що для студентів 2 курсу, які навчаються за даною методикою, проблемно-орієнтоване навчання слугує не для отримання клінічних знань, а для вивчення базових дисциплін (анатомія, патологічна анатомія, фізіологія, патологічна фізіологія, гістологія, біохімія, фармакологія тощо) в контексті конкретної клінічної ситуації. В цілому на вивчення кожного кейсу і пов’язаних з ним питань відводиться один тиждень. Структура занять протягом такого тижня наступна:

- 6 годин проблемно-орієнтованого навчання (заняття $з$ тьютором);

- 3 години лекцій (вівторок, середа, п’ятниця);

- 1 година практичних занять (п’ятниця);

- самостійна робота студентів протягом тижня.

Заняття студентів з тьюторами проводяться у 4 аудиторіях, що знаходяться на базі факультету післядипломної освіти, лекції - в аудиторії № 7 головного навчального корпусу та аудиторії дистанційного навчання спортивно-аудиторного корпусу, практичні заняття - на базі клінічних кафедр, які відповідають за конкретний кейс.

Структура як лекцій, так і практичних занять на базі клінічних кафедр дещо відрізняється від класичної. Частина кожної лекції присвячена викладенню необхідних базових, або клінічних знань, частина відводиться під дискусію між лектором, як експертом у даному клінічному питанні, та студентами. Практичне заняття також орієнтоване не на перевірку знань студентів, а на те, щоб продемонструвати їм необхідні клінічні навички, які студенти могли би потім вдосконалити, наприклад, під час самостійної роботи з манекенами або при роботі у групі між собою.

3 використанням платформи OpenLabyrinth були створені 17 віртуальних пацієнтів на базі кейсів для першого та другого років навчання студентів у рамках програми. Проведені заняття передбачали формування досить невеликих академічних груп по 8 студентів 3 курсу медичного факультету з використанням платформи OpenLabyrinth віртуальних пацієнтів на базі кейсів для другого року навчання.

Професорсько-викладацький склад кафедр відзначає серед академічних груп, що брали участь у проекті, більшу пізнавальну активність, мотивованість, комунікативність, легкість проходження дискусійних етапів в обговоренні навчального матеріалу. Практично всі студенти успішно навчаються, за вказаний період контингент груп залишався незмінним. Тобто, не проходячи первинного відбору за академічною успішністю при вступі до проекту, за результатами його проходження відзначається позитивна динаміка у результатах навчання серед вказаних груп.

Матеріально-технічне оснащення для навчального процесу. Для виконання завдань проекту його планом також передбачено обладнання кімнати для проведення тренінгів. 3 цією метою було устатковано сучасним навчальним обладнанням 4 кімнати для практичних занять та 1 залу для лекцій та підсумкових занять. Не менш важливим, ніж оснащення Центру необхідним обладнанням та матеріалами, є одержання його постійними співробітниками та іншими працівниками ЗДМУ, які будуть залучені до виконання завдань Tempus-проекту ePBLnet, необхідних навичок, кваліфікацій, методичних та навчальних матеріалів.

Основними заходами в цьому напрямку є тренінги з питань проблемно-орієнтованого навчання, тре- 
нінги 3 підготовки викладачів-тьюторів, з питань адаптації матеріалів, необхідних для проблемноорієнтованого навчання, зі створення віртуальних пацієнтів. План більшої частини тренінгів було складено університетом св. Георга (Лондон, Великобританія), а самі тренінги здійснювалися переважно персоналом даного університету.

Створення електронної он-лайн бібліотеки. У рамках проекту на базі ЗДМУ було розроблено концептуальну модель електронної бібліотеки для збереження та використання матеріалів, підтримки навчальних тижнів з проблемно-орієнтованого навчання, створити дану бібліотеку, а також наповнити її необхідними матеріалами.

При проектуванні функціональної моделі за цілями та завданнями можна виділити такі підсистеми проекту:

1) підсистема формування змісту, що розуміє функцію “Збір інформації”. Цільова функція: освітні ресурси для завантаження в бібліотеці;

2) підсистема створення нового контенту для реалізації цілей програми, що реалізує функцію “Створити”. Цільова функція: створення нового контенту у вигляді навчальних об’ єктів, курсів, 3D моделей тощо;

3) підсистема бібліотеки, що реалізує функцію “Шаринг”. Цільова функція: зберігання і доставка цифрового контенту за запитом користувача.

Аналіз концептуальної моделі електронної бібліотеки дозволяє виділити три основні категорії користувачів, що взаємодіють з системою, які мають різні права доступу до електронної бібліотеки, залежно від їх функцій:

1) користувачі адміністратори - мають право розробити структуру електронної бібліотеки, створити обліковий запис для груп користувачів, форму і супроводжувати бази цифрового контенту;

\section{Список літератури}

1. Искренко Э. В. Проблемно-ориентированное обучение: особенности методики преподавания в Великобритании (на примере St. George university of London, great Britain) / Э. В. Искренко, Т. А. Полтон // Научные ведомости Белгородского государственного университета. Серия: История. Политология. - 2008. - Т. 8, № 10 (50). - C. 214-218.

2. Donner R. S. Problem-based learning in American medical education: an overview / R. S. Donner, H. Bickley // Bull Med. Libr. Assoc. - 1993. - № 81(3). - P. 294-298.
2) користувачі вчителі - формування, створення і пост змісту на сайті бібліотеки. Слід зазначити можливість повторного використання контенту при створенні нових навчальних об’ єктів і віртуальних пацієнтів;

3) члени студенти - мають право використовувати ресурси бібліотеки.

Дисемінація результатів проекту. У рамках проекту “ePBLnet” було проведено низку конференцій та круглих столів. 11 жовтня 2013 р. відбувся Круглий стіл у рамках конференції “Актуальні питання дистанційної освіти та телемедицини2013”. 6 червня 2014 р. проведено Всеукраїнський віртуальний семінар “Особливості організації проблемно-орієнтованого навчання на базі віртуальних пацієнтів студентів медичних ВНЗ у рамках проекту програми Темпус”. 7 жовтня 2014 р. відбувся Круглий стіл “Проблемно-орієнтоване навчання в медичній і фармацевтичній освіті”. 22 квітня 2015 р. - Всеукраїнська науково-методична конференція з міжнародною участю “Впровадження інноваційних технологій в медичну освіту: проблемно-орієнтоване навчання та віртуальні пацієнти”. 12 листопада 2015 р. проведено відеоконференцію з міжнародною участю “Актуальні питання дистанційної освіти та телемедицини 2015”. Дані заходи дозволили поширити знання, а також досвід ЗДМУ та зарубіжних партнерів в області проблемно-орієнтованого навчання серед ВНЗ України.

Висновки. Стратегія проблемно-орієнтованого навчання в медичній освіті передбачає наближення системи підготовки майбутніх фахівців до вимог європейського та світового рівнів, вимагає впровадження сучасних інноваційних технологій у процесі організації та здійснення освітнього процесу.

3. Schmidt H. G. Longterm effects of problem-based learning: a comparison of competencies acquired by graduates of a problem-based and a conventional medical school / H. G. Schmidt, L. Vermeulen, H. T. Van Der Molen // Medical Education. - 2006. - Vol. 40, Issue 6. P. 562-567. 